\title{
AMHERST MEETING
}

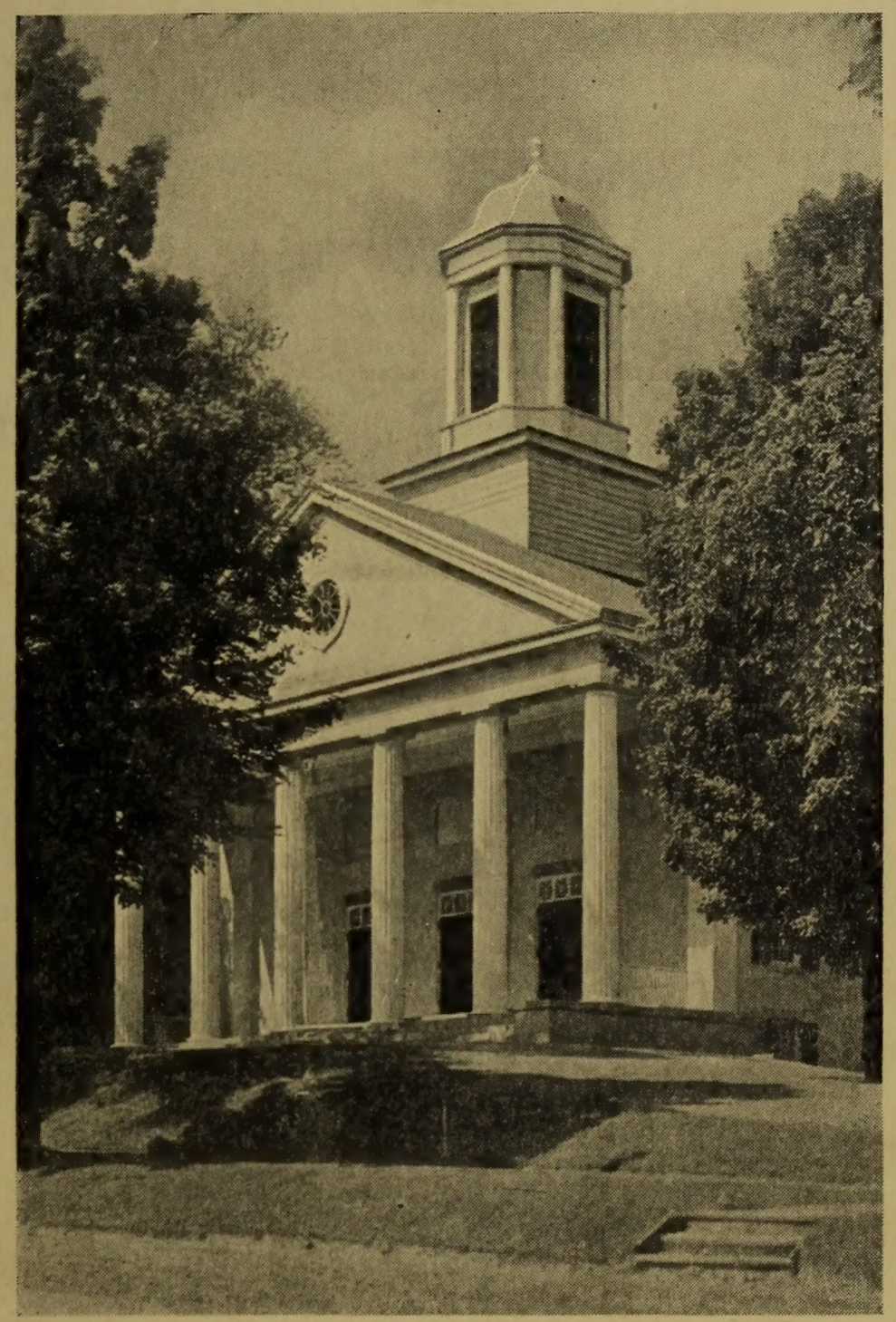

COLLEGE HALL

GEOLOGICAL SOCIETY OF AMERICA PALAEONTOLOGICAL SOCIETY MINERALOGICAL SOCIETY OF AMERICA SOCIETY OF ECONOMIG GEOLOGISTS

December 28-30, 1921 
Inuth

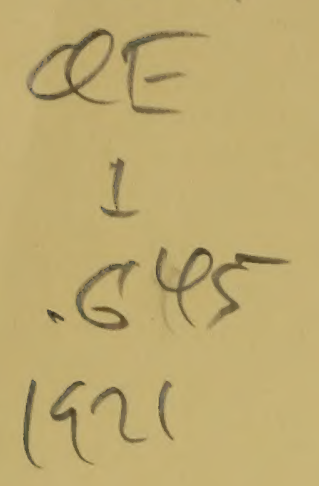

Enst nay literery

Musurn of Conpratio Zocky Harvand Unveraty 


\section{AMHERST MEETING \\ OF THE}

GEOLOGICAL SOCIETY OF AMERICA.

PALAEONTOLOGICAL SOCIETY,

MINERALOGICAL SOCIETY OF AMERICA.

AND

SOCIETY OF ECONOMIC GEOLOGISTS

December 28-30, 1921 


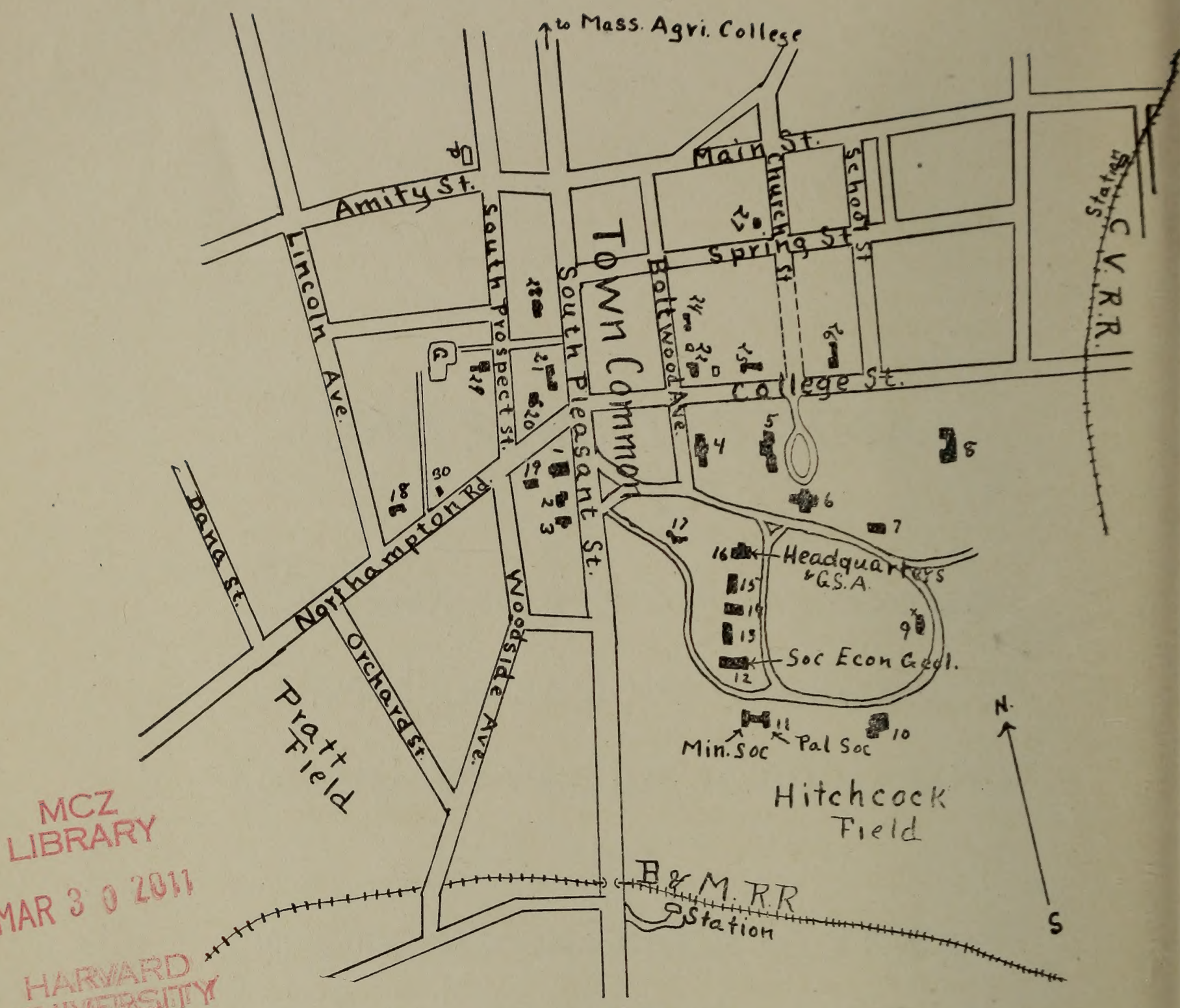

AMHERST

1 College Hall

4 Converse Library

5 Pratt Dormitory

11 Geology and Biology Building

12 Appleton Cabinet

16 Williston Hall
19 Phi Delta Theta House

20 Chi Psi House

21 Psi Upsilon House

22 Beta Theta Pi House

24 Delta Upsilon House

25 Chi Phi House

29 Carters's for meals

30 College Inn for meals

d Perry Hotel

\section{MEETING PLACES}

Headquarters and loafing rooms, Williston Hall (16)

Geological Society of America, Williston Hall (16)

Palaeontological Society, Geology-Biology Building (11)

Mineralogical Society of America, Geology-Biology Building (11)

Society of Economic Geologists, Appleton Cabinet (12)

Annual Smoker and Dinner College Hall (1)

Exhibition Room, Williston Hall (16) 


\section{GENERAL INFORMATION}

Headquarters are on the first floor of Williston Hall. Everyone should go there at once and register, and get programs and information.

Guests and Visitors are heartily welcome to all the gatherings of the various societies, and are asked to register also.

Rooms in the College Dormitories and Fraternity Houses are $\$ 1.50$ per night. These are studies, usually with two bed rooms, each with a single bed, and adjoining the study. There are a few, with only a study and one bed room. Ladies will have one of the fraternity houses reserved for them. Fellows bringing their wives will have also a fraternity house reserved for them. Each fraternity house and dormitory has one or two parlors for general gathering. In case a hotel is preferred the rates at the Perry are, rooms $\$ 2.00$ and up, meals $\$ 2.75$.

Meals will be provided at two (or if necessary three) of the best student boarding houses at the rate of $\$ .50$ for breakfast, $\$ .75$ for luncheon and $\$ 1.00$ for dinner. Please arrange at Headquarters as to which boarding house you will go to, so that congestion may not occur at individual points.

If possible arrange beforehand for your rooms and meals, writing to F. B. Loomis, Amherst, Mass., the secretary of the Local committee. Otherwise make arrangements on arrival at Headquarters.

Annual Smoker and Dinner. The Local Committee must know by noon of Wednesday the number of those planning to attend. The tickets are $\$ 1.00$ at Headquarters. Those planning to attend the annual dinner should make it known by $10 \mathrm{~A}$. M. of Thursday. Tickets $\$ 3.00$ at headquarters.

Mail during the sessions will be distributed at Headquarters, if sent care of F. B. Loomis, Amherst, Mass. Also papers or packages sent in advance of the meeting may be sent in care of F. B. Loomis.

An Exhibition Room is provided for such exhibits as members may bring or send in. In this room will also be found maps of the region, historical data, and other objects of general interest.

Train schedules of trains coming to Amherst are found in the back of this booklet. Outgoing schedules will be found at Headquarters. Thursday afternoon, Dec. 29, a representative of the railroads will be at headquarters to arrange for reservations on 
sleepers. As travel is heavy at this time, members wishing space reserved should write to F. B. Loomis, Amherst, Mass., a week or so beforehand what reservations they would like, giving date and train; and the space will be held for them. Tickets and payments will be arranged for at headquarters, Thursday, Dec. 29. 


\section{OUTLINE PROGRAM}

Wednesday, Dec. 28

9.30-12.30 First general session of Geological Society of America. Williston Hall.

2.00-5.00 Session of Geological Society in two sections, both in Williston Hall.

First session of Palaeontological Society,

Geological Lecture Room.

8.00 P. M. Address of retiring President J. F. Kemp,

College Hall.

9.00 P. M. Smoker of all the societies in College Hall.

Thursday, Dec. 29

9.30-12.30 A. M. Session of the Geological Society,

Williston Hall.

Session of the Palaeontological Society,

Geological Lecture Room.

First session of the Mineralogical Society,

Biological Lecture Room.

First session of the Society of Economic Geologists,

Appleton Cabinet.

2.00-5.00 P. M. Session of the Geological Society,

Williston Hall.

Session of the Palaeontological Society,

Geological Lecture Room.

Session of the Mineralogical Society,

Biological Lecture Room.

Session of the Economic Geologists,

Appleton Cabinet.

7.00 P. M. Annual Dinner of the Geological Society and its friends. The Palaeontological Society, the Mineralogical Society of America, the Society of Economic Geologists will participate. 
Friday, Dec. 30

9.30-12.30 A. M. Session of the Geological Society,

Williston Hall.

Session of the Palaeontological Society,

Geological Lecture Room.

Session of the Mineralogical Society,

Biological Lecture Room.

Session of the Society of Economic Geologists,

2.00-5.00 P. M. Session of the Geological Society,

Appleton Cabinet.

Session of the Palaeontological Society,

Williston Hall.

Geological Lecture Room.

Session of the Mineralogical Society,

Biological Lecture Room.

Session of the Society of Economic Geologists,

Appleton Cabinet.

\section{GEOLOGY OF AMHERST}

The geology about Amherst is, in general, that of the Connecticut Valley, but in the immediate vicinity of the town there is considerable variation from the typical development of the valley as a whole. Many of the most typical structures and evidences of dynamic changes can be seen from College Hill, or better still from the balcony just outside the geology lecture room.

The Connecticut Valley is a lowland, extending from just north of Greenfield, Mass., 95 miles to New Haven, Conn., and varying in width from some five miles at either end to $15-18$ in the middle. It is an uncompleted Tertiary peneplain on the soft Triassic sandstone, between an eastern and a western upland of crystalline rocks of sufficient hardness to have preserved considerable of the old Cretaceous peneplain, which extended over most of New England.

The western upland, referred to in Massachusetts and Connecticut as the Berkshire Hills, lies on folded igneous and metamorphic rocks of Lower Cambrian to Silurian age. These rocks show evidences of two disturbances, first the folding which made mountains at the end of the Lower Cambrian, known as the Green Mountain uplift. This mountain system, extending along the western border of the present Berkshire region was eroded to its roots, and then covered by marine sediments of Ordovician and Silurian ages; 
after which a second disturbance in the Devonian folded them again and lifted the Berkshire region far above sea level. This system of mountain ranges remained until eroded to the level of the Cretaceous peneplain, some elevations however remaining on that plain as monadnocks, like Greylock; and the Green Mountains.

The eastern upland is the southern extension of the White Mountain highlands south through Massachusetts and Connecticut, and consists of igneous and metamorphic rocks of Cambrian to Pennsylvanian age, folded into a mountain system during the Pennsylvanian. Through the succeeding time down to the Cretaceous these were reduced toward the level of the Cretaceous peneplain. Again some points were left above the plain, such as peaks in the White Mountains, Mt. Katahdin in Maine, Mt. Monadnock in New Hampshire, and Mt. Wachusett in Mass.

The Connecticut Valley lowland differs greatly in its history. Some time in the Triassic epoch a series of great faults developed in Eastern North America. Between some of these great faults great blocks dropped down, in Nova Scotia, in Connecticut and Massachusetts, and in New Jersey and Pennsylvania. The Connecticut Valley approximates one of the great rift valleys thus formed. Just how deep the valley was at any one time can not be said, for probably the down dropping block took its final position as the result of a series of movements; but to fill the hole thus formed, it took some 10,000 feet of deposits. Of course as soon as such a valley was formed, gravel, sand and clay was washed in from the sides, and the filling began. The coarsest material is near the sides, the finer near the middle. Most of the fill is conglomerate and sandstones, but there are bands of shale, some of it blackened by organic matter.

In general the first part of the fill is conglomerates and sandstone, varying from some 300 to over 1000 feet in thickness. When this had been laid down volcanic eruptions toward the south end of the valley produced a sheet of lava, some 250 feet thick in the south and thinning out until it is lacking above the Massachusetts line. In Connecticut this is termed the "anterior sheet." Above this there is a further fill of 2000 to 3000 feet of conglomerates and sandstones, on top of which were poured out the "main sheet" of lava (termed in Massachusetts the Holyoke trap), a sheet generally 400-500 feet thick, but thinner near the northern end of the valley. Another period of in washing accumulated 1000 to 2000 feet more of sandstones, etc., followed by the third volcanic period when another thinner layer was poured into the valley. This is 250 or so feet 


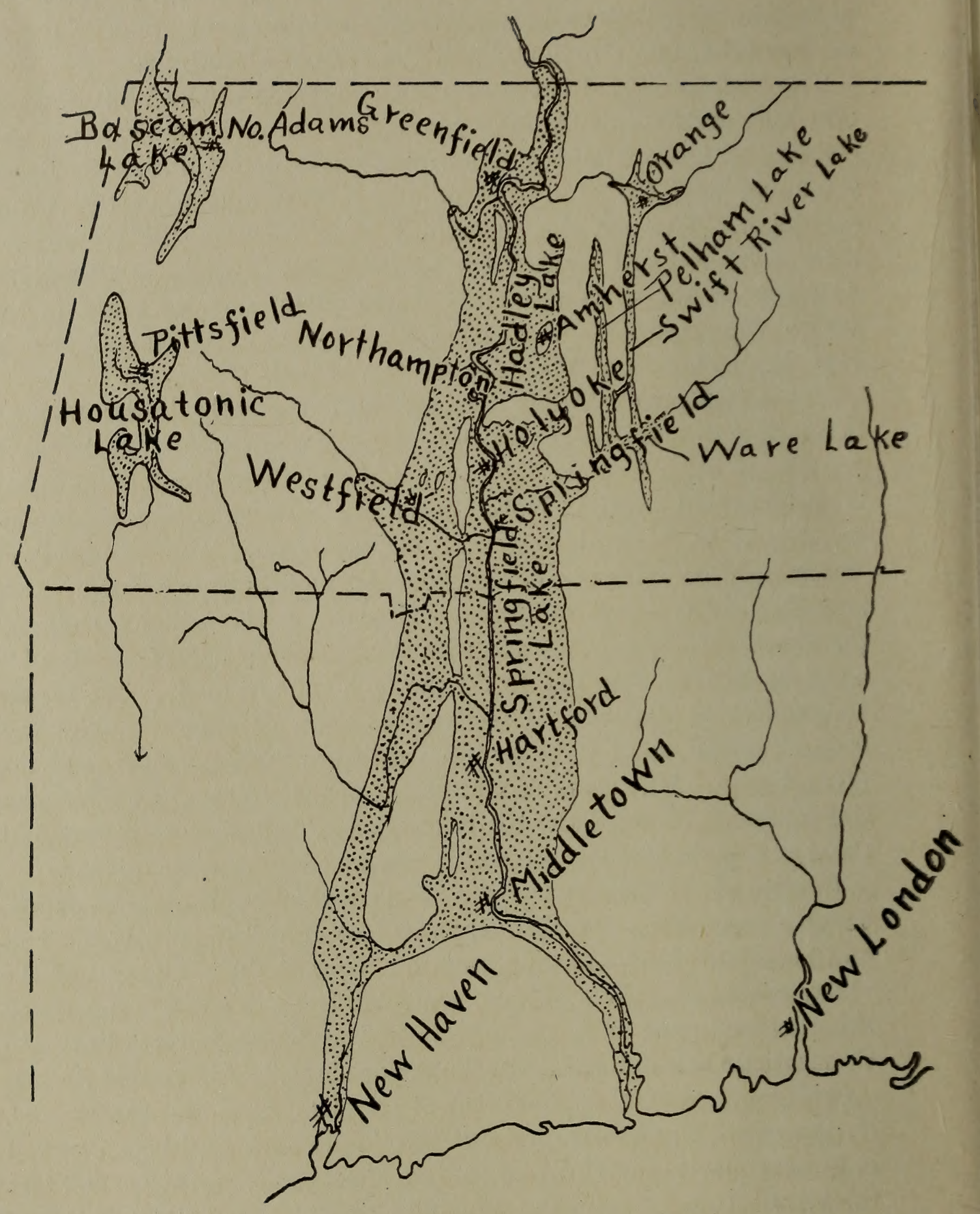

Fig. 1. Outlines of the larger postglacial lakes in Western Massachusgtts. 
thick, and known in Connecticut as "the posterior sheet," or in Massachusetts as the Hampden trap, and extends north as far as the Holyoke Range. This period was followed by a continuation of the volcanic activity, when explosive eruptions took place and the next 200 feet or more of sands are mixed with greater or less quantities of volcanic ash. Above this there are still some thousand feet of sands mostly of finer character than the earlier deposits, until the valley was filled.

After the accumulation of these sandstones and lavas, probably in the Jurassic, a second period of faulting took place, breaking the Triassic deposits and adjacent crystalline rocks into a complex of smaller blocks, and tilting these at various angles, but mostly so that the blocks dip to the east. Some blocks just south of Amherst. were caused to dip south, and the block or blocks of the Amherst region were lift higher than the others. This is the block mountain period of the region.

During the remainder of the Jurassic and through Comanchian and Cretaceous times, all the New England country, both the eastern and western highland and the Connecticut Valley block mountains, was being eroded to a great plain near sea level, the Cretaceous Peneplain, regardless of the hardness of the various. rocks; excepting only the monadnocks mentioned above.

During the latter part of the Cretaceous, the New England peneplain experienced a broad uplift (not entirely uniform), amount-. ing in the Amherst region to about 1200 feet. This rejuvenated. the streams and they began again to carve out valleys, and carry the loosened material away to the sea. The Triassic sandstones. were relative soft and were rapidly removed down to about sea level, at which level a new plain began to be formed, about as extensive as were the Triassic deposits. The trap layers, which had been tilted about in the Jurassic block-forming movement, when uncovered, were more resistant and so stood out as mountain ranges in the valley, the exposed edge making generally north and south ridges. with the steep slope to the west and the gentle slope to the east. Thus the Tom Range and Talcott Mts. and the Pocumtuck Ridge came into existence. The blocks tilted toward the south, when eroded, uncovered the east and west edge of the trap layers and therefore made an east-trending ridge, the Holyoke mountains. For ten miles north of this range the blocks had been lifted so high, that the Triassic material was mostly carried away and where Amherst stands (including Mt. Warner and a strip to the north of 
the town), the original floor of the valley was uncovered, and appears as a slight elevation above the level of the rest of the lowland. In general then the rock floor of the Connecticut Valley represents this Tertiary plain which was developed in the softer sandstones. Beginning with Mt. Toby and Sugarloaf the normal character of eastward dipping blocks begins again and continues to the north end of the valley. The small hill on which Amherst stands and Mt. Warner are composed of so called Amherst Schist which is of Pennsylvanian age. Thus the general contour of the Valley was completed about the end of the Miocene. (See Fig. 2, page 15.)

Just after this a new uplift took place and the streams began anew to cut deep valleys and seek a new base level. This was only attained in the soft Triassic material, for in the Crystalline rocks the Micoene base level had hardly been attained when the second uplift took place. The Connecticut River cut a deep gorge, like that of the Hudson River, but before any general widening took place, the ice sheet of the Pleistocene spread over the whole country and buried it. This undoubtedly scraped off some material and reduced the irregularities, but did not materially alter the general contour. During this period of being covered with ice there was a general depression of the whole country until the Tertiary plain was below present sea level.

When the ice melted and the sheet retreated, leaving behind a boulder strewn surface and irregular moraines, it exposed a surface so low that drainage was impeded.

This low lying valley immediately filled with water making a great lake. This great body of water was divided by the Holyoke Range and its continuation the Tom Range and the Talcott Range into two main bodies. What was north and west of these ranges is called the Hadley Lake, while the water to the south and east of the ranges is the Springfield Lake. The two however were connected at several points by continuous water ways, one where the Connecticut River originally crossed the Holyoke Range, and another where the Westfield River did the same. The old Lake shore approximates the 300 foot level of today. and in many places can be easily seen as terraces of gravel or sand. The lake bottom was gradually covered with layers of clays varying from 10 to 180 feet thick, which today are exposed in the numerous clay pits worked by the brick making industries. (Fig. 1.)

Amherst stands on what was an island in the lake, and the shoreline is easily traced, appearing as the terrace just south of the geology 
building and extending around back of the church and Walker Hall. Counting the layers of clay and figuring that each represents an annual deposit, the lake lasted some 4000 years.

Then came the postglacial uplift of New England, amounting to around 100 feet at the south end of the valley and over 600 in middle New Hampshire. In this region it was around 300 feet. The lake, thus tipped up at its northern end quickly drained away; and the Connecticut River sought out a channel over the low parts of its bottom, into which it has cut thirty to fifty feet deep at the present time. In flood times it has spread over the clay of the lake bottom a varying layer of sand and loam, which makes the tobacco and onion soil of this section.

Probably associated with this uplift are numerous recent faults in the Toby group, and in the Holyoke Range, which vary in height from 5 to 100 feet in displacement. Near Sunderland one of these has cut the old shore line and for a distance of four miles dropped it from 80 to 50 feet below where it should normally appear in that region. These were the last geologic events in the valley and since then it has stood so little altered that this last disturbance must have been very recent.

\section{WHAT TO SEE COMING TO AMHERST}

In coming to Amherst various bits of the foregoing history can be readily seen from the car window.

Coming from Albany, just before reaching Pittsfield, extensive gravel banks indicate where the west shore of the postglacial Lake Housatonic lay while the flats about Pittsfield were the lake bottom, the east shore being seen also in gravel beds near Dalton. After a short climb over the divide, the railroad begins its descent from the western upland by winding down the valley of the Westfield River, and enters the Connecticut Valley and the Postglacial Lake Hadley basin about four miles west of Westfield. The gravel embankment to the north of the railroad is part of the delta which the Westfield River made in Lake Hadley. Three miles east of Westfield the road and river pass through a notch in the Mt. Tom Range which is caused by a fault and was a waterway connecting Lakes Hadley and Springfield. The rest of the way to Springfield is over the bottom of former Lake Springfield. 
From Springfield the Boston and Maine R. R. goes north to Holyoke along the Connecticut River. The clay pits to the east show the deposits in the middle of Springfield Lake, and are topped with sands which were bars, etc. washed out into the lake in its later phases. The flats near the river are terraces which the Connecticut River has cut in postglacial times. At Holyoke the R. R. crosses to the west side of the river and runs along the foot of the Tom Range. (Mt. Tom is the one with a house on it three miles north of Holyoke). Also about three miles north of the city one sees ledges in the river. On these and also just west of the tracks ripple marks and reptile tracks are well exposed. Two miles north of the Smith's Ferry station the track crosses the Hampden trap, and half a mile further the Holyoke trap, arriving at once at Mt. Tom station. Here the mountain on the west is Nonotuck, while across the river to the east is Mt. Holyoke. Just beyond this station is a fine oxbow of the Connecticut River, from which the road goes over a broad river terrace into Northampton.

From Northampton the railroad or trolley goes over the Hadley Lake bottom, skirting the edge of a broad low river terrace on the south; until the river is crossed, after which the way is over the Hadley Lake bottom. About a mile from Amherst the trolley begins to climb out of the lake bottom and at Prospect St. crosses the shore line and is on the Amherst Island. All the way from Northampton the Holyoke Range is seen some three miles to the south, while to the north can be seen Mt. Sugarloaf and the Toby group some eight miles away.

Coming from Boston on the Boston and Maine the eastern highland begins at Oakdale. A little west of Rutland the railroad begins to descent following the Ware River. At Ware and from there to Belchertown one is on the sands and gravels of the narrow posglacial lakes associated with the branches of the Chicopee River, especially the Ware and Swift Rivers, along which were the lakes known as Shutsbury and Pelham Lakes. Just north of Belchertown lie the Belchertown Ponds, which are kettle holes formed by the melting of the last remnants of the ice, covered by the earliest shore beds of postglacial Lake Hadley. From here one continues to Amherst over the bottom of this extinct lake, skirting along the north side of the Holyoke Range.

On the Boston and Albany coming from Boston the eastern upland begins at Worcester, and the railroad is crossing it until it gets about three miles west of Palmer, when it enters the Connect- 
icut Valley proper and the Springfield Lake basin. (See Springfield to Northampton).

The New York, New Haven and Hartford railroad crosses the low lying southern end of the Berkshires and enters the Connecticut Valley three miles west of New Haven. East Rock and West Rock are small trap ridges. The railroad then continues over the Tertiary peneplain to Meriden, the trap ridges being mostly to the east. Then it crosses through the ridges and comes out some ten miles south of Hartford into the Springfield Lake bottom, and on over this Lake bottom into Springfield, the trap ridges being now on the west side. (See Springfield to Northampton).

\section{COLLECTIONS TO BE SEEN AT AMHERST COLLEGE}

The Hitchcock Collection of fossil footprints is in the basement at the east end of the Geology-Biology building. It consists of slabs of Triassic sandstone from the Connecticut Valley, on which the tracks of reptiles, insects and worms of the time can still be traced. The tracks were probably made in mud puddles or near them, then baked by the hot sun, and thus hardened so that they were not destroyed when new layers of mud were spread over them. As the process was repeated thousands of feet of sandy muds were piled over the tracks and, when cemented, preserved them. Even the impress of ripple marks and rain drops are preserved. The collection contains over 20,000 tracks representing some forty different kinds of animals.

The collection of fossil vertebrates is on the first floor at the east end of the Geology-Biology building. The striking forms in this are the evolution of the horse represented by five stages, Eohippus, Mesohippus, Merychippus, Equus Scotti, and the modern horse. There are skeletons of early camels, rhinoceros, dogs, oreodonts, saber-toothed cat, etc., and considerable material from the Miocene and Oligocene periods. Here also is the collection of Oligocene vertebrates from Patagonia of which the Pyrotherium skull is most interesting.

The historical geological collection is on the second floor of the same building and is arranged in alcoves each alcove to show the typical life of that period. The features of especial note are the history of the Connecticut Valley at the east end of the room, the mastodon skeleton from South Carolina, the evolutionary material 
of the elephants, the fishes of the Connecticut Valley Triassic formation, the Permain reptiles, the Patagonian invertebrates, and the jaws of the giant Miocene shark. At the west end of the GeologyBiology building is the Shepard Collection of minerals. This was gathered and brought to a high degree of perfection by Prof. C. U. Shepard many years ago. Then it went through a fire, the choicest specimens escaping as they had been removed from the room preparatory to rearrangement. Prof. Emerson then rebuilt the collection to its present still better development. It is rich in choice crystals, and rare gems. The tourmalines and rutiles are especially noteworthy.

On the east side of the same room is one of the world's large collections of meteorites, gathered by Prof. Shepard and Prof. Emerson. It is notable for a considerable number of complete meteorites and for the large number of falls represented.

On the first floor of this same building there is a biological collection, in which the Audubon birds and books, and the Birds of Amherst are of especial interest.

Those interested in Indian relics will find a large collection on the second floor of Appleton Cabinet, some 30,000 pieces, representing the work of Indians from all parts of America. But it is especially rich in material representing the local Algonquins, and the Iroquois of the Lake Champlain and Lake George regions.

\section{SKETCH MAP OF THE CONNECTICUT VALLEY.}

Fig. 2. Sketch map of the northern half of the Connecticut Valley, A, western highland; B, eastern highlands; A.s., Amherst schist ; G, Granby tuff; Hm, Hampden trap; H.t., Holyoke trap; L.B., lake bottom deposits; P.g., Pelham gneiss; T.1., lowest Triassic sandstone; T.2, Triassic sandstone between the Holyoke and Hampden traps; T.3., Upper Triassic sandstones; Wg., Williamsburg granodiorite. 
1.0.

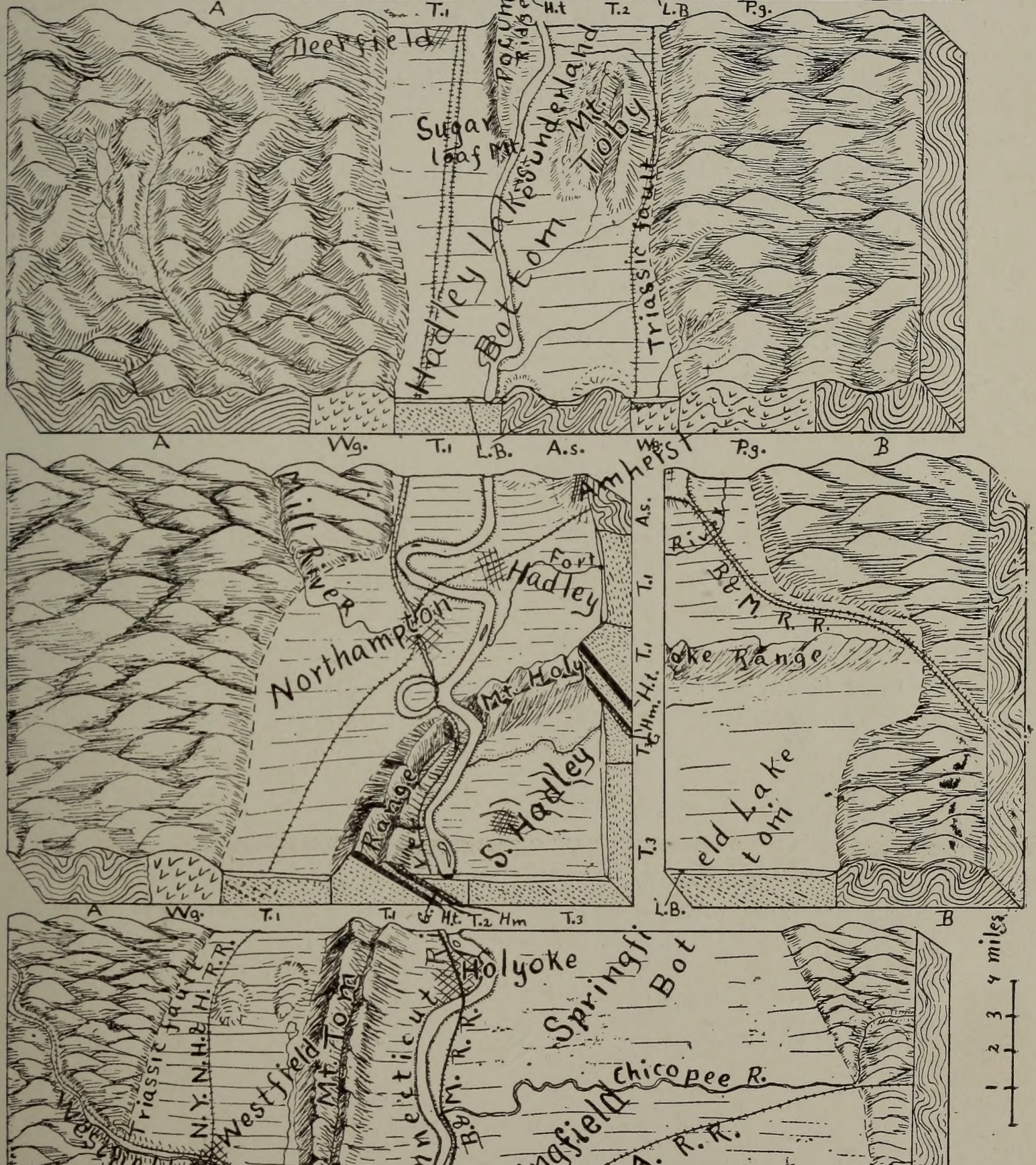

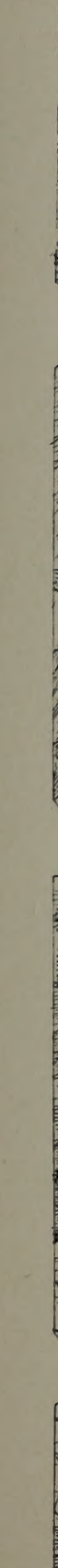

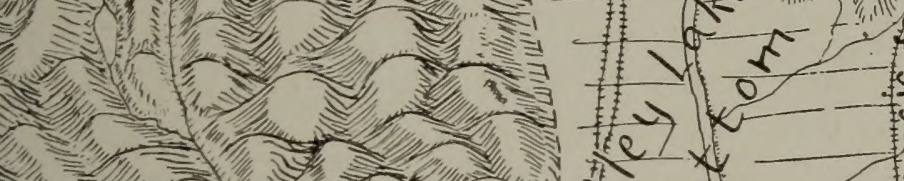

1.

Qt
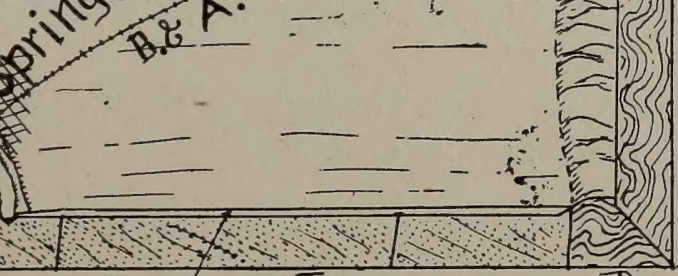

H.t.T. $\mathrm{Hm}_{\text {. }}$ T.3

Fig. 2. 


\section{TRAIN SCHEDULES}

The best way to reach Amherst in general is to come to Northampton, by way of Springfield, Mass. and take the trolley over, getting off at College Hall, which is the nearest point to Headquarters. From Boston one may come direct wover the Boston and Maine R. R.

From Boston, via the Boston and Maine R. R.
Leave Boston
8.05 A. M.
Arrive Amherst
5.44 P. M.

$$
11.57 \text { A. M. }
$$$$
\text { 9.28 P. M. }
$$

From Springfield to Northampton, via the Boston and Maine R. R. Leave Springfield, Mass.
$6.50 \quad 7.05$
7.05
3.38
8.00
$12.20 \quad 3.38 \quad 5.10$
9.15
5.45
10.30 A. M.
$6.35 \quad 8.00$
11.00 P. M.*
arriving forty minutes later.

*If this train is taken, get off at Holyoke and take trolley to Amherst.

Leave Boston for Springfield via the Boston and Albany R. R.

$\begin{array}{cccc}\text { Leave Boston } & \text { Arrive Springfield } & \text { Leave Boston } & \text { Arrive Springfield } \\ 7.05 \mathrm{~A} . \mathrm{M} . & 10.10 \mathrm{~A} . \mathrm{M} . & 12.30 \mathrm{P} . \mathrm{M} . & 2.49 \mathrm{P} . \mathrm{M} . \\ 8.30 & 11.10 & 1.00 & 3.40 \\ 9.15 & 11.45 & 2.00 & 4.30 \\ 10.00 & 12.35 \mathrm{P} . \mathrm{M} . & 2.10 & 4.40 \\ 12.00 \text { noon } & 2.38 & 2.30 & 5.50 \\ & & 4.00 & 6.25 \\ & & 5.50 & 8.25 \\ & & 6.10 & 8.45 \\ & & 7.35 & 10.20\end{array}$

From Albany for Springfield via the Boston and Albany R. R.

$\begin{array}{cccc}\text { Leave Albany } & \text { Arrive Springfield } & \text { Leave Albany } & \text { Arrive Springfield } \\ 6.45 \text { A. M. } & 9.32 \text { A. M. } & 1.30 \text { P. M. } & 5.10 \text { P. M. } \\ 6.55 & 11.05 & 2.42 & 5.50 \\ 9.15 & 12.38 \text { P. M. } & 5.00 & 8.20 \\ 12.30 \text { P. M. } & 3.37 & 5.15 & 8.55\end{array}$

From New York to Springfield via New York, New Haven and Hartford R. R. Leave New York Arrive Springfield Leave New York Arrive Springfield

$\begin{array}{lccc}7.43 \mathrm{~A} . \mathrm{M} . & 11.54 \mathrm{~A} . \mathrm{M} . & 3.45 \mathrm{P} . \mathrm{M} . & 7.23 \mathrm{P} . \mathrm{M} . \\ 9.15 & 12.52 \mathrm{P} . \mathrm{M} . & 4.00 & 7.28 \\ 11.00 & 3.13 & 5.02 & 8.50 \\ 12.00 \text { noon } & 3.28 & 6.00 & 10.10 \\ 1.03 \text { P. M. } & 5.40 & 8.00 & 12.26 \mathrm{~A} . \mathrm{M} . \\ 2.20 & 6.26 & 10.15 & 3.38 \mathrm{~A} . \mathrm{M} \text {. sleeper } \\ & & & \text { until } 7.00\end{array}$

\section{TROLLEY SCHEDULE}

Cars leave Northampton for Amherst every hour on the hour, and at 4.30 and 5.30 .

Cars leave Amherst for Northampton every hour on the half hour, and at $4.00,5.00$ and 6.00 . 


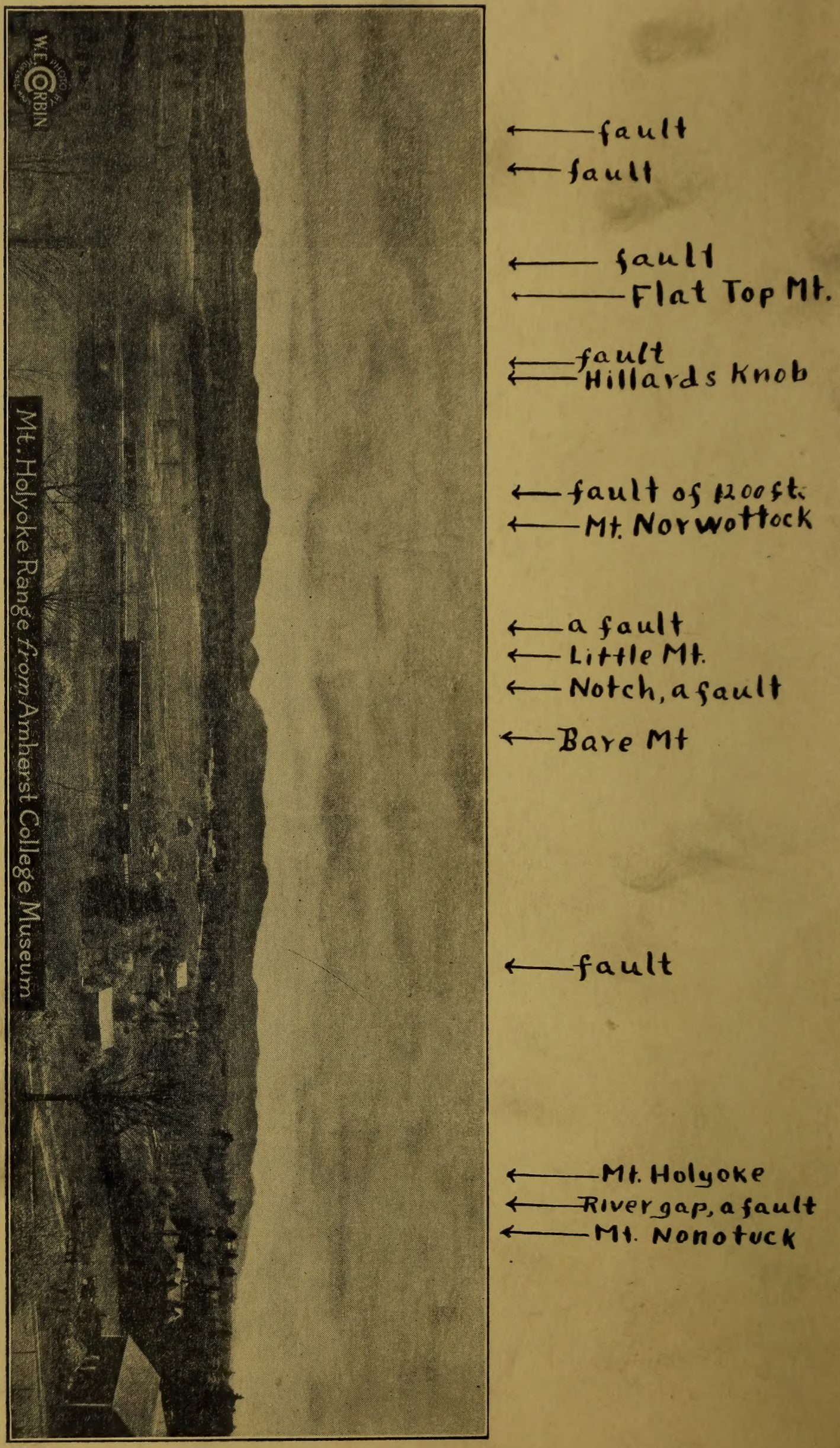

